\title{
Letter from the Editor-in-Chief: The JIBS Decade Award: Integrating international acquisitions
}

\section{Lorraine Eden}

Journal of International Business Studies (2010) 41, I-4. doi: I 0. I057/jibs.2009.84

\section{THE 2009 JIBS DECADE AWARD}

The first issue of JIBS each year begins with a reprint of the article that won the previous year's JIBS Decade Award, followed by a Retrospective written by the author or authors, and one or more invited Commentaries. The 2009 award-winning article is "Knowledge transfer in international acquisitions" by Henrik Bresman, Julian Birkinshaw and Robert Nobel, published in 1999 (JIBS 30.3).

The JIBS Decade Award recognizes the most influential article published in the volume 10 years ago. The 2009 Selection Committee members were Stephen Tallman (chair), Torben Pedersen (2009 AIB Program Chair), John Cantwell (2008 AIB Program Chair) and the JIBS Editor-in-Chief as an ex officio member. The award is presented by Palgrave Macmillan during a special session honoring the authors at the annual meeting of the Academy of International Business (AIB). The 2009 AIB session in San Diego was chaired by the JIBS Editor-in-Chief; Julian Birkinshaw spoke on behalf of the authors, and Alain Verbeke and Udo Zander provided commentaries.

After the conference, the presentations were revised, sent out for single blind review to selected JIBS Area and Consulting Editors, and also circulated among the authors to encourage crossfertilizing of ideas. The end product, I believe, is a wonderful set of papers that should - and will - be read together, and I suspect often assigned as a set for PhD seminars. I thank all the Area and Consulting Editors who read these manuscripts and provided such thoughtful comments for the authors.

The first paper in this issue of JIBS is a reprint of the Decade Award winning article by Bresman, Birkinshaw and Nobel. The article is a qualitative study of the post-acquisition integration process in three international acquisitions by Swedish multinationals. The authors argue that successful acquisitions create a social community where two-way knowledge sharing occurs between the acquirer and acquired firms.

The reprinted article is followed by "Knowledge transfer in international acquisitions: A retrospective" by Birkinshaw, Bresman and Nobel. The Retrospective explores the origins of their awardwinning article, situating it in the knowledge-based view of the multinational enterprise (MNE) (Kogut \& Zander, 1993). They argue that their paper makes three contributions to the international business (IB) literature: mapping out the territory, comparing the 
factors that facilitate sharing of technical know-how vs patent-based knowledge, and clarifying that past-acquisition integration is a multi-stage process. The Retrospective calls for more qualitative, creative and experimental research in IB, with the admonition that "it has to be well done". The paper concludes by exploring how the post-acquisition integration literature has moved over the past 10 years and where the authors believe it is headed.

The first Commentary, "Opening the grey box: Social communities, knowledge and culture in acquisitions" by Udo and Lena Zander, culturally and institutionally situates the Bresman et al. (1999) article and argues that it is important because (1) it is an early empirical test of the knowledge-based view; (2) international acquisitions are a central theme in IB; (3) the article is a forerunner to current work on metanationals; and (4) most importantly, Bresman et al. (1999) find that knowledge flows are facilitated by the creation of a social community. An international acquisition, for the Zanders, should be seen as a "grey box" because the acquirer does not know everything about its target acquisition. Information asymmetries make it very difficult to take stock of technical competence, workings of complex routines, critical cultural issues, and higher-order organizing principles. Therefore, the authors argue, heavy socialization is a perfectly rational strategy for learning about the target, which is useful even if the acquirer should aim at "vacuuming" the target with regards to technology or wish to impose its own systems and procedures. The authors explore the roles played by procedural integration, socialization, type of knowledge transfer and qualitative cultural differences in opening the grey box.

The second Commentary, by Alain Verbeke, "International acquisition success: Social community and dominant logic dimensions", first reviews Bresman et al. (1999) and then situates the article within two dimensions of acquisitions success: (1) construction of a unified social community and (2) diffusion of the acquirer's dominant logic from the acquirer to the acquisition. Verbeke argues that the former, the social community perspective, is the subject of Bresman et al. (1999). Verbeke argues, however, that the optimal mix of efforts towards the two dimensions of post-integration success, social community creation and transfer of dominant logic, depends on the desired reverse knowledge transfers by the acquirer and the commonality in dominant logic between the two firms. High-desired reverse transfers and high commonality in dominant logic together encou- rage social community creation; in other cases, the acquirer's routines may need to be imposed in full for successful post-acquisition integration. The type of acquisition (e.g., R\&D, manufacturing, services) also can affect the optimal mix between top-down diffusion of the acquirer's dominant logic and bottom-up social community building. Each dimension of integration success has different benefits, costs and time profiles. Verbeke concludes that neither measure of integration success is achievable using the "100-day" rule (completing acquisitions in 3 months) often advocated by consultants, particularly in sensitive acquisitions such as R\&D units.

\section{OTHER HIGHLIGHTS OF JIBS 41.1}

The remainder of this issue consists of six articles and a research note; four of the articles and the note were submitted under the previous editorial team, but all the manuscripts were completed with my editorial team.

The first article, "What makes and what does not make a real option? A study of equity shares in international joint ventures" by Cuypers and Martin, examines the boundaries of real options logic as it applies to international joint ventures. The authors distinguish between endogenous and exogenous uncertainty, arguing that only exogenous uncertainty will lead to the "wait and see" option (Rivoli \& Salorio, 1996) because firms can "assess and act on" sources of endogenous uncertainty (such as cultural distance) using strategies other than ownership-share selection. A particularly interesting and useful twist to this article is the use of null hypothesis testing by looking at the range of size effects rather than mean values, that is, looking for the range of possible size effects that are (not) supported by the data. The authors conclude that real options theorists must pay more attention to exogenous vs endogenous uncertainty if their predictions are to matter.

Southam and Sapp in "Compensation across executive labor markets: What can we learn from cross-listed firms?" examine differences in CEO compensation packages across countries. Using matched sets of Canadian and US firms, the authors find that the big difference between US and Canadian CEO compensation packages occurs only between US and Canadian non-cross-listed firms. There is no "US premium" for Canadian firms that are cross-listed on the US stock market. The authors find that cross-listed Canadian firms appear to compete in a common Canada-US market for 
managerial talent, where cross-listing drives the convergence between CEO compensation packages. This finding supports the long-held argument that Canadian firms need to adopt the "doublediamond" mindset, seeing North America as their market, not just Canada (Rugman \& D'Cruz, 1993). At least for cross-listed Canadian firms in the labor market for CEOs, the double diamond appears to be a reality.

Faccio, Lang and Young in "Pyramiding vs leverage in corporate groups: International evidence" focus on cross-country differences between equity and debt as risk-sharing instruments for firms, for a sample of five European Union and nine East Asian countries. In countries where creditor protection is strong, the authors find that wider separation of ownership from control is associated with lower leverage (debt-equity ratio). Shareholders that seek to control more resources tend to use either leverage or pyramiding, but not both methods, due to their different risk-sharing implications. However, where creditor protection is weak, controlling shareholders tend to use both pyramiding and leverage to extract resources, seeing both methods as having similar risk-sharing implications. A particularly interesting part of their paper is their focus on related party loans, whereby the MNE uses intracorporate loans to move funds among the group (an example of fiscal transfer price manipulation). Such loans are often restricted by thin capitalization rules, but the authors argue these rules are seldom enforced, especially in emerging economies. The authors conclude by calling for improved creditor protection, arguing that stronger capital market institutions would dampen incentives for pyramiding and leverage in corporate groups.

"Openness, hedging incentives and foreign exchange exposure: A firm-level multi-country study" by Hutson and Stevenson explores the disadvantages of exchange rate exposure to firms in open economies. Using a sample of 23 developed economies over the 1984-2003 period, the authors find that the more open an economy is to international trade, the more exposed its firms are to exchange rate movements. (Firms in small open economies such as Canada and Sweden can attest this is true.) The authors also find that where shareholder rights are strongly protected, firms are more likely to hedge their foreign exchange exposure; thus, better corporate governance encourages value-enhancing risk management activities by firms. Reading this article together with the article by Faccio, Lang and Young leads to the unambiguous public-policy conclusion that there is strong support for governments strengthening their home-country corporate governance regulations.

"A cross-country study on the effects of national culture on earnings management" by Han, Kang, Salter and Yoo links the likelihood of managers exercising earnings discretion to managerial values (i.e., Hofstede's individualism and uncertainty avoidance cultural characteristics) and home-country regulatory institutions (i.e., the degree of investor protection). Using a sample of 18,609 firms in 32 countries over the 1992-2003 period, the authors find that individualism is positively related, and uncertainty avoidance negatively related, to earnings discretion. Investor protection independently reduces the magnitude of earnings discretion. However, cultural factors and investor protection interact with each other, such that strong investor protection is positively associated with greater earnings discretion in highly individualistic and/or high uncertainty avoiding cultures. Interestingly, the results in this article appear to run counter to the results in Southam and Sapp and in Hutson and Stevenson. In those articles, stronger investor protection leads to less directly unproductive activities by managers (less pyramiding and excessive leverage, more use of hedging), whereas in this article by Han et al., the firms are more likely to engage in earnings discretion - but only in countries with highly individualistic and riskavoiding cultures. For the reader, the conundrum can be resolved by attributing the different outcomes to the important role that culture plays in managerial behavior and firm performance. As IB scholars know, not only regulatory institutions but also cultural institutions matter in international business.

In their article "How much does home country matter to corporate profitability?" McGahan and Victer provide a careful and thorough decomposition of the relative importance of home-country, industry and firm-level influences on corporate profitability, for firms with varying degrees of multinationality over the 1993-2003 period. Interestingly, the authors find that MNEs perform better than domestic firms, even when their degree of multinationality is low. As expected, home-country and industry effects are more important for domestic firms than for MNEs, but even for MNEs with high degrees of multinationality, home-country effects matter. The authors call for more work in 
three areas to evaluate the mechanisms by which domestic firms and MNEs absorb home-country influences on firm performance: the dynamic process of home-country imprinting on the firm, the persistence of home-country effects and the differences between home and host country influences. Reading this article together with the three previous articles suggests that home-country corporate governance institutions do matter for firms' valueenhancing risk management activities, and therefore for corporate profitability.

The issue concludes with a research note that brings us full circle back to international acquisitions and the JIBS Decade Award. "A real options perspec-

\section{REFERENCES}

Bresman, H., Birkinshaw, J., \& Nobel, R. 1999. Knowledge transfer in international acquisitions. Journal of International Business Studies, 30(3): 439-462.

Kogut, B., \& Zander, U. 1993. Knowledge of the firm and the evolutionary theory of the multinational corporation. Journal of International Business Studies, 24(4): 625-645. tive on sequential acquisitions in China" by $\mathrm{Xu}$, Zhou and Phan explores how emerging market firms can open the "grey box" of international acquisitions (see Zander and Zander in this issue). The authors argue that the information disadvantage for the acquirer can be reduced by engaging in a sequential acquisition strategy. Looking at 272 acquisitions of Chinese-listed firms between 1995 and 2003 provides support for their argument in cases where the acquirer is a private firm or diversifying into a new area. Thus, the authors recommend that acquirers open the grey box of an international acquisition through the cautious "getting one's feet wet" strategy of sequential acquisitions.

Rivoli, P., \& Salorio, E. 1996. Foreign direct investment and investment under uncertainty. Journal of International Business Studies, 27(2): 335-357.

Rugman, A. M., \& D'Cruz, J. R. 1993. The "double diamond" model of international competitiveness: The Canadian experience. Management International Review, 33(2): 17-39. 